\title{
Istota sprawiedliwego wynagrodzenia w zarządzaniu - aspekty teoretyczne i realne
}

\author{
Marta Juchnowicz \\ Instytut Kapitału Ludzkiego, Kolegium Nauk o Przedsiębiorstwie, \\ Szkoła Główna Handlowa w Warszawie
}

\begin{abstract}
Znaczenie kapitału ludzkiego, a także zmiany zachodzące w systemie wartości pracowników, wyrażające się wzrostem wrażliwości na sprawiedliwość społeczną, uzasadniają wzrost zainteresowania analizą sprawiedliwego wynagrodzenia jako kategorii, która wywiera różnorodne konsekwencje dla zarządzania w skali mikroekonomicznej, a więc z perspektywy organizacji i jednostki. Celem artykułu jest eksploracja teoretyczna i empiryczna istoty sprawiedliwości wynagradzania. Złożoność tej kategorii wymaga analizy z kilku perspektyw: jakościowych cech wynagrodzenia za pracę, skuteczności systemu wynagrodzeń w organizacji oraz percepcji indywidualnego pracownika. Artykuł zawiera także ocenę różnych aspektów sprawiedliwego wynagradzania na podstawie opinii osób pracujących w polskiej gospodarce. Na tej podstawie są formułowane zarządcze konsekwencje sprawiedliwego wynagrodzenia w skali organizacji.
\end{abstract}

Słowa kluczowe: wynagrodzenie za pracę, sprawiedliwe wynagrodzenie, wynagrodzenie godziwe, system wynagrodzeń

\section{Wprowadzenie}

Zagadnienie sprawiedliwego wynagradzania pozostaje pod wpływem szerokiego kontekstu czynników, dlatego jest rozpatrywane z perspektywy różnych dyscyplin i koncepcji naukowych: filozofii, psychologii pracy i organizacji, socjologii, prawa pracy, ekonomii. Istotny wkład wniosła społeczna doktryna Kościoła katolickiego. Aktualne znaczenie kapitału ludzkiego w kreowaniu kapitału intelektualnego jako źródła innowacyjności w skali makro i mikro uzasadnia potrzebę analizy sprawiedliwego wynagrodzenia jako kategorii, która wywiera różnorodne 
konsekwencje dla zarządzania kapitałem ludzkim. Taka perspektywa badawcza jednoznacznie sytuuje przedmiot rozważań w naukach o zarządzaniu, koncentrując się na skali mikroekonomicznej, a więc z perspektywy organizacji i jednostki. Łączy ona podejście humanistyczne z biznesowym, z uwzględnieniem celów szerokiego grona interesariuszy (Juchnowicz, 2014, s. 132-136). Równocześnie poszerza zakres analizy, podkreślając jego interdyscyplinarny charakter. Studia literatury na temat sprawiedliwego wynagrodzenia wskazują na izolacjonizm w podejściu do jego analizy, co niewątpliwie stanowi jeden z powodów niskiej skuteczności aplikacyjnej. Autorka podejmuje starania, by dowieść, że kategoria sprawiedliwego wynagrodzenia powinna łączyć ideały i wartości społeczeństwa demokratycznego z efektywnością ekonomiczną oraz paradygmat normatywny z pragmatycznym idealizmem.

Celem artykułu jest eksploracja teoretyczna i empiryczna istoty sprawiedliwości wynagradzania jako kategorii z dziedziny zarządzania, z uwzględnieniem aspektów socjopsychologicznych. Przedmiotem badania są czynniki determinujące ocenę poziomu sprawiedliwości wynagrodzeń. Autorka formułuje hipotezę, że głównym czynnikiem kształtującym poczucie sprawiedliwości wynagrodzeń są opinie pracowników na temat relacji wynagrodzeń.

Artykuł składa się z dwóch części. W części pierwszej przedstawiono istotę i zakres sprawiedliwego wynagrodzenia $z$ trzech różnych perspektyw: jakościowych cech wynagrodzenia za pracę, skuteczności systemu wynagrodzeń w organizacji oraz percepcji indywidualnego pracownika. Część druga artykułu zawiera analizę wybranych aspektów sprawiedliwego wynagradzania na podstawie badania opinii osób pracujących w polskiej gospodarce ${ }^{1}$. Wnioski z badania literaturowo-empirycznego są podstawą wskazania implikacji zarządczych w skali organizacji.

\section{Renesans zainteresowania sprawiedliwością wynagradzania}

Współczesne megatrendy (globalizacja światowej gospodarki, rozwój nowych technologii, starzenie się społeczeństw, cyfryzacja otoczenia) powodują zmiany w konkurowaniu przedsiębiorstw. Dominującym źródłem przewagi konkurencyjnej staje się kreatywność i innowacyjność pracowników, kapitał organizacyjny i relacyjny, a więc wszystko to, co jest efektem potencjału kompetencyjnego pracowników, będącego w dyspozycji organizacji. Megatrendy wywierają również

1 Artykuł powstał w wyniku realizacji projektu badawczego nr 2016/21/B/HS4/02992 pt. Sprawiedliwość wynagradzania, finansowanego ze środków Narodowego Centrum Nauki. 
wpływ na zmiany w systemie wartości pracowników (Vielmetter, Sell, 2014, s. 62). Oczekiwania i potrzeby reprezentantów pokolenia Y i Z, które zaczynają dominować wśród zatrudnionych, różnią się znacznie od oczekiwań poprzednich pokoleń. Reprezentanci tych dwóch generacji w swych działaniach w większym stopniu niż poprzednie pokolenia kierują się poczuciem sprawiedliwości społecznej. Oceny w tym zakresie determinują podejmowane przez nich decyzje o wyborze pracodawcy, formie zatrudnienia, zmianie miejsca pracy. Znaczenie emocji w kształtowaniu realnej gospodarki potwierdzają wyniki badań (Koźmiński, 2017, s. 22). Dlatego A.K. Koźmiński wyraża pogląd, że współczesna ekonomia powinna się stać w większym stopniu ekonomią społecznych emocji. Jak wykazują badania, przy wyborze pracodawcy kandydaci do pracy coraz częściej zwracają uwagę na spójność działalności przedsiębiorstwa $\mathrm{z}$ ich indywidualnym systemem wartości (Boston Consulting Group, Inc. and World Federation of Personnel Management, 2008, s. 47, 59). Sprzyja temu ułatwiony dostęp i wymiana informacji o działalności przedsiębiorstwa, np. dzięki mediom społecznościowym.

Wzrost wrażliwości na sprawiedliwość społeczną oraz postępująca indywidualizacja systemu wartości i potrzeb poszczególnych ludzi, w warunkach wzrostu znaczenia kapitału ludzkiego, wymagają uwzględnienia w procesie zarządzania etycznych aspektów działalności biznesowej. Reakcją organizacji jest zainteresowanie koncepcją społecznej odpowiedzialności biznesu (CSR) oraz budowaniem marki pracodawcy (employer branding).

Równie niezbędna jest identyfikacja aktualnych źródeł motywacji pracowników i kreowania ich zaangażowania. W tym celu konieczne stają się zmiany w tradycyjnych systemach wynagradzania, czyli zarządzania wynikami, które stały się uciążliwym i nieefektywnym procesem w wielu przedsiębiorstwach (Deloitte University Press, 2015, s. 51). Zmiany te powinny polegać na zastąpieniu charakteru reaktywnego, czyli wynagradzania za przeszłe zdarzenia i osiągnięcia pracowników, systemem inspirującym, tzn. stymulującym zachowania i postawy oczekiwane w przyszłości, w tym przede wszystkim innowacyjność, permanentny rozwój, dzielenie się wiedzą. Jednym z istotnych warunków takich zmian są zasady i procesy zapewniające pracującym, bez względu na formę prawną świadczonej usługi, poczucie sprawiedliwego wynagrodzenia.

\section{Perspektywy analizy istoty sprawiedliwego wynagrodzenia}

Określenie „wynagrodzenie sprawiedliwe” jest pojęciem wzbudzającym szczególnie dużo kontrowersji. W naukach ekonomicznych istnieją skrajne poglądy, od uznawania za sprawiedliwe tego, co efektywne, do uznawania za efektywne 
tego, co sprawiedliwe (Borkowska, 1999, s. 21). Niektórzy badacze traktują je jako figurę wyłącznie retoryczną, a nawet zawierającą wyrażenia przeciwstawne. Inni, upraszczając, jako synonim zasady „tak samo”, „każdemu po równo”. Bywa również utożsamiane z pojęciem wynagrodzenia godziwego, co także nie jest uzasadnione.

\section{Cechy wynagrodzenia za pracę}

Złożoność istoty sprawiedliwego wynagrodzenia wymaga analizy z kilku perspektyw. Wynagrodzenie za pracę to ogół korzyści, jakie uzyskuje osoba z tytułu świadczonej przez siebie usługi pracy. Kategorię tę charakteryzują cztery cechy: poziom wynagrodzenia, tempo zmian, struktura wewnętrzna oraz zewnętrzna (relacje). Wymienione cechy wyznaczają zakres problemów wpływających na ocenę sprawiedliwości wynagrodzenia.

Perspektywa jakościowych cech wynagrodzenia znajduje odzwierciedlenie w określeniu prawa do sprawiedliwego wynagrodzenia w Europejskiej Karcie Społecznej (Europejska Karta Społeczna). Została ona uchwalona przez Radę Europy w 1961 r. (obowiązuje od 1965 r.) w celu określenia zasadniczych praw społecznych i ekonomicznych. Art.4 tejże Karty uwzględnia dwie z wymienionych cech, a mianowicie wymóg godziwego poziomu oraz relacje, uznając prawo do jednakowego wynagrodzenia za pracę jednakowej wartości. Podobne regulacje zawiera Kodeks Pracy (Ustawa..., 1974), który stanowi, że pracownicy mają prawo do jednakowego wynagrodzenia za jednakową pracę lub za pracę o jednakowej wartości, która występuje, gdy pracownicy mają porównywalne kwalifikacje zawodowe i doświadczenie zawodowe oraz gdy praca wymaga od nich porównywalnej odpowiedzialności i wysiłku zarówno psychicznego, jak i fizycznego (Ustawa..., 1974, art. $18^{3 \mathrm{c}}$ ).

Wymóg wynagrodzenia godziwego został wskazany w Kodeksie Pracy (Ustawa..., 1974) odrębnie, poprzez zapis art. 13: „Pracownik ma prawo do godziwego wynagrodzenia za pracę. Warunki realizacji tego prawa określają przepisy prawa pracy oraz polityka państwa w dziedzinie płac, w szczególności poprzez ustalanie minimalnego wynagrodzenia za pracę". Instrument ten uwzględnia wyłącznie jeden czynnik kształtowania wysokości wynagrodzeń - poziom kosztów utrzymania uznanych za niezbędne w danych warunkach społeczno-ekonomicznych. Poza tym, o wysokości wynagrodzenia za pracę decydują czynniki rynkowe (podaż i popyt na dane usługi, wyniki finansowe firmy), specyficzne determinanty społeczne (dynamika wzrostu stopy życiowej, relacje wynagrodzeń) oraz polityczne (konwergencja wynagrodzeń, siła partnerów społecznych).

Badania dowodzą, że problem relacji wynagrodzeń ma kluczowe znaczenie. Poczucie niesprawiedliwych relacji eliminuje wszystkie inne pozytywne 
oceny cech wynagrodzenia. Analizy odpowiedzi ponad 125 tys. respondentów Ogólnopolskiego Badania Wynagrodzeń 2015 (za: Kulikowski, 2017) dowiodły, że wysokość miesięcznego wynagrodzenia słabo się wiąże z oceną sprawiedliwości wynagrodzeń. K. Kulikowski (2017, s. 227) konstatuje: „[...] wbrew intuicyjnym przekonaniom, wysokość zarobków jest bardzo słabo powiązana z postawami pracowników wobec pracy i wynagrodzenia”.

\section{Skuteczność systemu wynagrodzeń w organizacji}

Według D. Vaughan-Whiteheada (2011, s. 2-3), sprawiedliwe wynagrodzenia charakteryzuje, poza poziomem i relacjami wynagrodzeń, także mechanizm ustalania, przy jednoczesnym przestrzeganiu przepisów prawa pracy. Autor formułuje dwanaście czynników, które jego zdaniem wpływają na poczucie sprawiedliwości wynagrodzenia (tabela 1).

Tabela 1. Determinanty sprawiedliwego wynagradzania z perspektywy systemu wynagrodzeń

\begin{tabular}{|c|c|c|}
\hline Lp. & Czynnik & Interpretacja \\
\hline 1 & Wypłata wynagrodzenia & wypłacane regularnie oraz w sformalizowanej formie \\
\hline 2 & Wynagrodzenie godziwe & zapewnia minimalne akceptowalne standardy życia \\
\hline 3 & Wynagrodzenie minimalne & $\begin{array}{l}\text { zgodne z przepisami dotyczącymi wynagrodzenia } \\
\text { minimalnego }\end{array}$ \\
\hline 4 & $\begin{array}{l}\text { Wynagrodzenie } \\
\text { porównywalne }\end{array}$ & $\begin{array}{l}\text { do wynagrodzeń w podobnych przedsiębiorstwach } \\
\text { w tym samym sektorze }\end{array}$ \\
\hline 5 & Czas pracy & $\begin{array}{l}\text { odpowiednio wynagradza normalne godziny pracy oraz } \\
\text { pracę w godzinach nadliczbowych }\end{array}$ \\
\hline 6 & System wynagrodzeń & $\begin{array}{l}\text { - zapewnia zrównoważoną strukturę wewnętrzną } \\
\text { - uwzględnia różne poziomy wykształcenia, } \\
\text { umiejętności i doświadczenia zawodowego, a także } \\
\text { indywidualne i zbiorowe wyniki pracy } \\
\text { - jest zgodny z przepisami }\end{array}$ \\
\hline 7 & $\begin{array}{l}\text { Komunikacja i dialog } \\
\text { społeczny }\end{array}$ & $\begin{array}{l}\text { szczegółowe informacje; negocjowane indywidualnie } \\
\text { i zbiorowo }\end{array}$ \\
\hline 8 & $\begin{array}{l}\text { Dyskryminacja płacowa/ } \\
\text { dysproporcje płacowe }\end{array}$ & $\begin{array}{l}\text { równe wynagrodzenie za taką samą pracę, która nie } \\
\text { prowadzi do dyskryminacji płacowej oraz nie generuje } \\
\text { nieuzasadnionych, zbyt wysokich i zbyt gwałtownie } \\
\text { rosnących różnic płacowych w przedsiębiorstwie }\end{array}$ \\
\hline 9 & Poziom realny & wzrasta co najmniej proporcjonalnie do wzrostu cen \\
\hline 10 & Udział w efektach & $\begin{array}{l}\text { wzrasta proporcjonalnie do wzrostu sprzedaży } \\
\text { przedsiębiorstwa i wzrostu zysku oraz nie prowadzi do } \\
\text { spadku udziału wynagrodzeń we wzroście wydajności }\end{array}$ \\
\hline
\end{tabular}




\begin{tabular}{|c|l|l|}
\hline Lp. & \multicolumn{1}{|c|}{ Czynnik } & \multicolumn{1}{c|}{ Interpretacja } \\
\hline 11 & Koszty wynagrodzeń & nie prowadzi do obniżenia udziału w kosztach produkcji \\
\hline 12 & $\begin{array}{l}\text { Intensywność pracy, zmiany } \\
\text { technologiczne oraz wzrost } \\
\text { kwalifikacji }\end{array}$ & $\begin{array}{l}\text { uwzględnia zmiany natężenia pracy, zmiany } \\
\text { techniczno-technologiczne oraz kompetencyjne }\end{array}$ \\
\hline
\end{tabular}

Źródło: Vaughan-Whitehead (2011, s. 2-3).

Poczucie sprawiedliwości wynagradzania w organizacji jest także determinowane przez transparentność systemu wynagradzania. Pracownik, który zna konstrukcję i zasady wynagradzania, a przede wszystkim kryteria ustalania wysokości wynagrodzeń, uznaje, że system jest sprawiedliwy. Według R. Rasch i M. Szypko (2013, s. 65-67), nawet gdy w organizacji wynagrodzenia nie są najwyższe, kluczową rolę odgrywają jawność systemu wynagradzania oraz jego skuteczna komunikacja.

Można więc stwierdzić, że istotę sprawiedliwego wynagrodzenia należy rozważać z perspektywy skuteczności systemu wynagradzania w organizacji. Opinia pracowników na temat sprawiedliwość wynagradzania w danej organizacji kształtuje się bowiem pod wpływem trzech czynników:

1) zrozumienia sposobu ustalania wysokości wynagrodzenia,

2) wiedzy, w jaki sposób można podwyższyć wysokość swojego wynagrodzenia,

3) mechanizmu wiążącego wysokość wynagrodzenia z efektami pracy.

\section{Sprawiedliwość wynagrodzenia z perspektywy jednostki}

Wśród różnych aspektów postrzeganej w organizacji sprawiedliwości, kluczowa jest równość wynagrodzeń, a zwłaszcza równość w rozkładzie wynagrodzeń i sprawiedliwość podziału (Carr i in., 2016, s. 15). Zgodnie z doktryną sprawiedliwości dystrybutywnej, za sprawiedliwe można uznać wynagrodzenie, które odpowiada wkładowi pracy $\mathrm{w}$ uzyskany sukces. Istotę sprawiedliwości dystrybutywnej konkretyzuje teoria słuszności J. Adamsa (1963, s. 432-436). Wynagradzanie jest uważane za sprawiedliwe wówczas, gdy stosunek nakładów jednostki (kompetencji, odpowiedzialności, wysiłku) do korzyści tejże jednostki (osiągniętych nagród zewnętrznych i wewnętrznych) jest równoznaczny z oceną takich relacji w przyjętej grupie porównawczej. Teoria J. Adamsa zwraca uwagę na subiektywne uwarunkowania oceny, która jest emocjonalną reakcją pracownika (Rasch, Szypko, 2013, s. 65-67). Dlatego wrażliwość na sprawiedliwość wynagrodzeń może być bardziej wyraźna przy niższych ich poziomach, poniżej mediany (Card i in., 2012, s. 2989). Indywidualny pracownik dokonuje oceny sprawiedliwości, biorąc pod uwagę trzy wymiary (Sekuła, 2013, s. 53-54): 
1) stosunek otrzymanego wynagrodzenia do włożonego wysiłku,

2) relację wysiłku innych pracowników do otrzymanego przez nich wynagrodzenia,

3) ocenę własnego wysiłku i otrzymanego wynagrodzenia w stosunku do innych pracowników.

Wymiary, decydujące o adekwatności wynagrodzenia za daną pracę w porównaniu z wynagrodzeniami uzyskiwanymi przez inne osoby za podobną pracę, stanowią jeden $z$ istotnych elementów systemu wartości i oczekiwań pracowników. Dlatego zasada ta jest istotnym warunkiem skutecznego motywowania przez wynagrodzenia (Borkowska, 2012, s. 32).

\section{Sprawiedliwość wynagrodzeń w realiach polskiej gospodarki}

Badanie sprawiedliwości wynagrodzeń zostało przeprowadzone metodą wywiadu telefonicznego (CATI) na reprezentatywnej próbie $(N=1067)$ pracujących Polaków. Wśród ankietowanych dominowały osoby w wieku 26-59 lat, mające wykształcenie zawodowe, średnie i wyższe (tabela 2).

Tabela 2. Struktura badanych według wieku i wykształcenia

\begin{tabular}{|l|c|}
\hline \multicolumn{1}{|c|}{ Opis } & Udział w \% \\
\hline \multicolumn{2}{|c|}{ Wiek } \\
\hline Poniżej 25 lat & 6 \\
\hline 26-34 lata & 31 \\
\hline 35-44 lata & 25 \\
\hline 45-59 lat & 32 \\
\hline Powyżej 60 lat & 6 \\
\hline & Wykształcenie \\
\hline Podstawowe & 24 \\
\hline Zasadnicze zawodowe & 35 \\
\hline Średnie & 33 \\
\hline Wyższe & \\
\hline
\end{tabular}

Źródło: opracowanie własne.

Istotną cechą badanej populacji w kontekście badanego zagadnienia jest także rozkład próby pod względem osiąganych dochodów (rysunek 1). Ponad 
połowa ankietowanych (56\%) osiągała dochód miesięczny netto w granicach 1401-3500 PLN, a dochód 16\% kształtował się wokół poziomu średniego.

Rysunek 1. Rozkład próby według wysokości miesięcznego dochodu netto

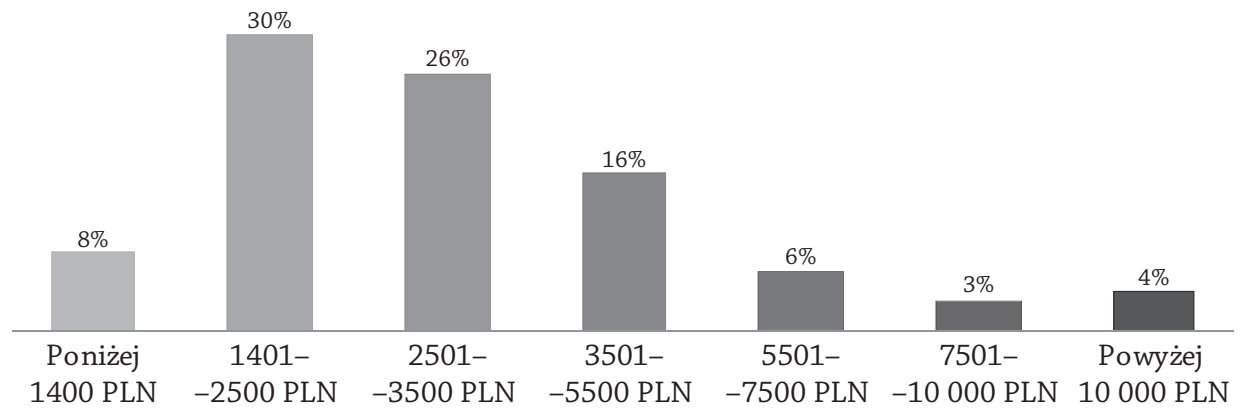

Źródło: opracowanie własne.

Analiza opinii respondentów wskazuje na pozytywną ocenę sprawiedliwości wynagrodzeń w polskiej gospodarce. Opinię taką wyraziło 52\% ankietowanych osób (rysunek 2). W tej grupie 25\% było zdecydowanych, a 27\% „raczej się zgadzało".

Rysunek 2. Moje aktualne wynagrodzenie jest sprawiedliwe

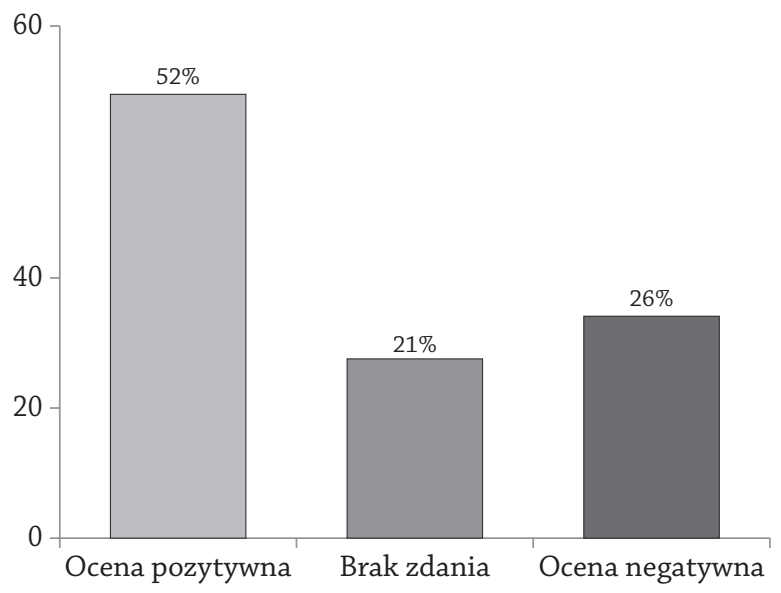

Źródło: opracowanie własne.

Wśród pracowników pozytywnie oceniających sprawiedliwość wynagrodzeń dominują osoby płci męskiej, w wieku 18-24 lata, mające wykształcenie podstawowe i wyższe, uzyskujące wynagrodzenie przekraczające 3501 PLN (rysunek 3). 
Rysunek 3. Rozkład oceny sprawiedliwości wynagrodzeń według głównych cech respondentów

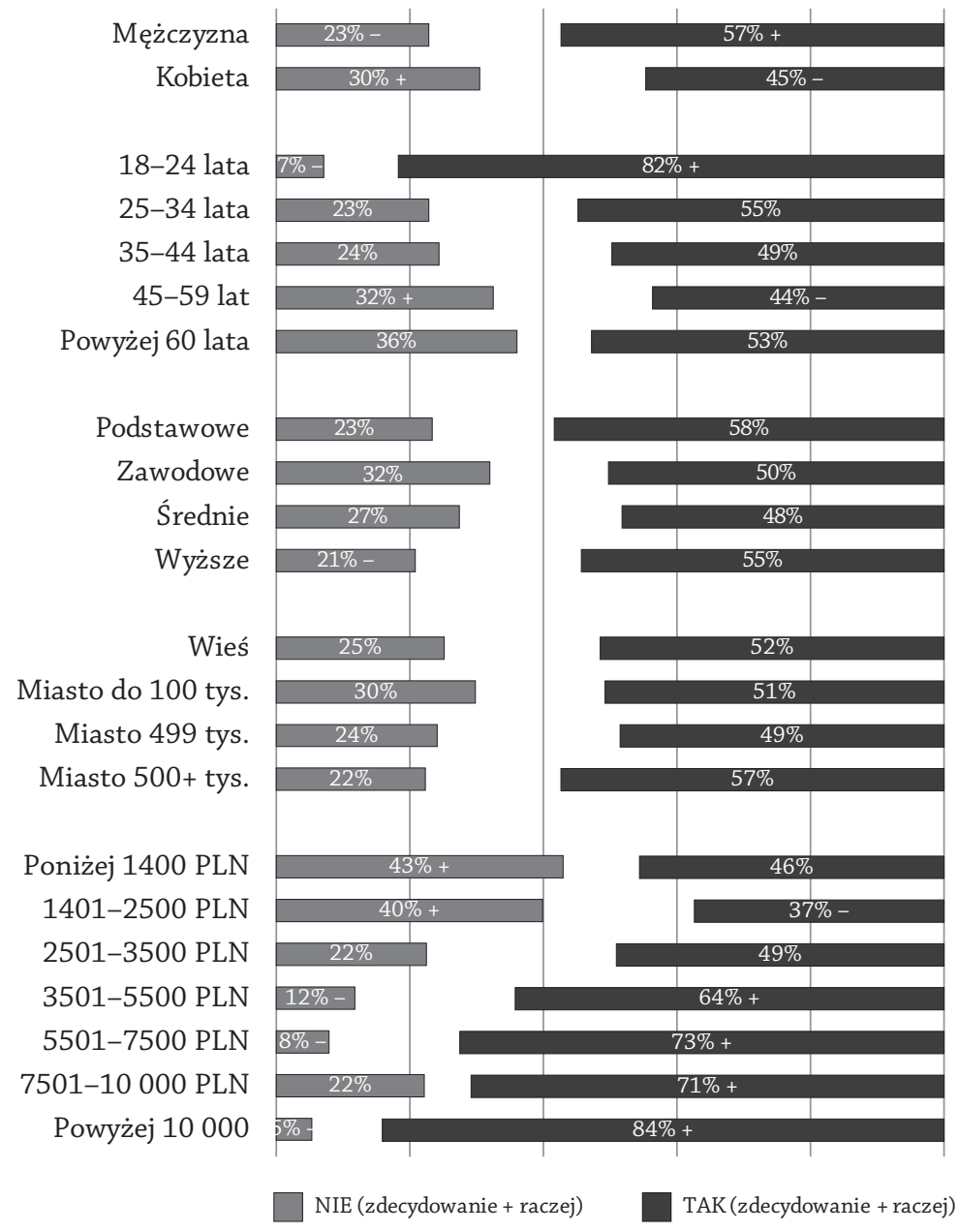

Uwaga: +/- różnice statystycznie istotne na poziomie 95\% w stosunku do wszystkich respondentów.

Źródło: opracowanie własne.

Rozkład opinii pracowników na temat równości w wynagrodzeniu, rozumianej jako adekwatne wynagrodzenie za podobną pracę, wskazuje, że jest to istotny czynnik determinujący pozytywną ocenę sprawiedliwości wynagrodzenia. Ocena czynnika równości wynagrodzeń koreluje z oceną sprawiedliwości. Współczynnik korelacji Pearsona wynosi 0,333. Uważa, że „Pracownicy wykonujący podobną pracę do mojej otrzymują podobne wynagrodzenie do mojego" 59\% respondentów, a 16\% nie ma jednoznacznej opinii. Tylko 17\% respondentów wyraża odmienną opinię (rysunek 4). 


\section{Rysunek 4. Pracownicy wykonujący podobną pracę do mojej otrzymują podobne} wynagrodzenie do mojego

Nie wiem \trudno powiedzieć

Zdecydowanie się zgadzam

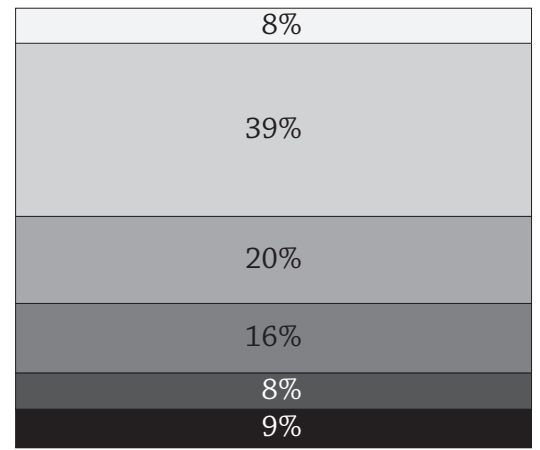

Źródło: opracowanie własne.

O ocenie sprawiedliwości wynagrodzenia decyduje także opinia pracujących na temat zróżnicowania wynagrodzenia. Uważa, że „Moje wynagrodzenie jest odpowiednie do pracy, którą wykonuję" 47\% ankietowanych (rysunek 5). Współczynnik korelacji między sprawiedliwością a tą cechą wynagrodzenia wynosi 0,770.

\section{Rysunek 5. Ocena zróżnicowania wynagrodzenia}

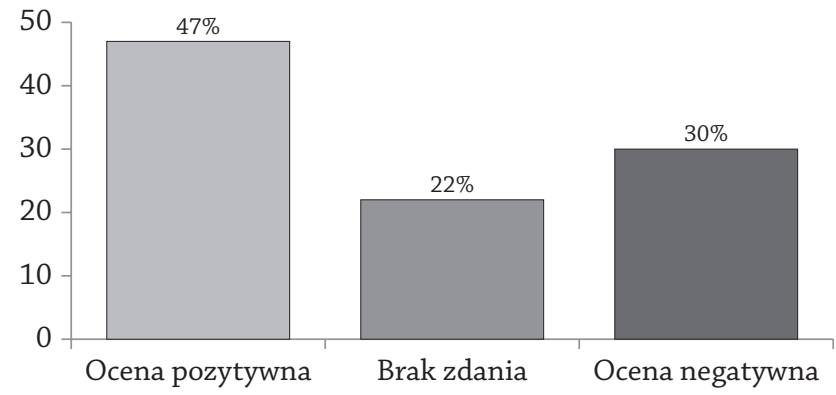

Źródło: opracowanie własne.

Przedstawione wyniki pozytywnie weryfikują hipotezę badawczą o kluczowym znaczeniu relacji wynagrodzenia dla poczucia sprawiedliwości. Równocześnie badania dowodzą, że mniejszy wpływ na ocenę sprawiedliwości wywierają opinie na temat poziomu nominalnego wynagrodzenia. Połowa ankietowanych pracowników (49\%) ocenia swoje wynagrodzenie jako satysfakcjonujące (rysunek 6). Aż $21 \%$ nie ma w tej sprawie zdania, a $30 \%$ respondentów wynagrodzenie nie satysfakcjonuje. 
Rys. 6. Moje wynagrodzenie jest dla mnie satysfakcjonujące

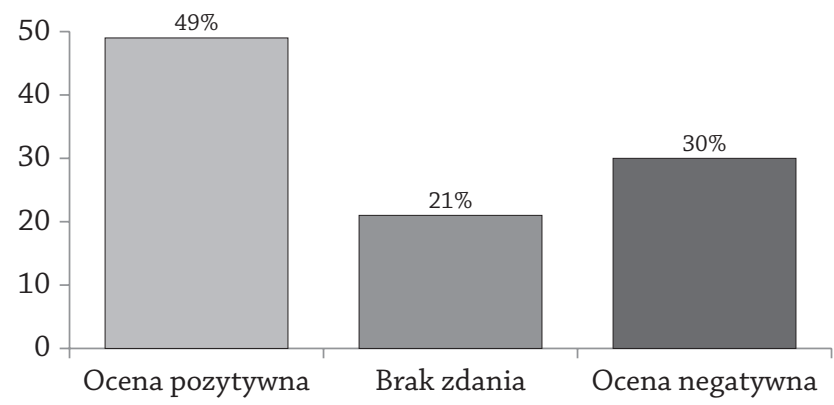

Źródło: opracowanie własne.

Wydaje się, że powodem niezadowalającej satysfakcji z wynagrodzeń jest poziom wynagrodzenia. Wśród respondentów tylko 13\% otrzymywało wynagrodzenie powyżej 5501 PLN (zob. rysunek 1). Co dziesiąty (9\%) deklaruje, że nie stać go na zaspokojenie potrzeb podstawowych i musi korzystać z pomocy innych, a co trzeci (29\%) ma możliwość zaspokojenia jedynie potrzeb na poziomie podstawowym (rysunek 7). W związku z tym, w grupie zdecydowanych na zmianę miejsca pracy $70 \%$ ankietowanych deklaruje chęć podjęcia takiej decyzji z powodu zbyt niskich wynagrodzeń.

\section{Rysunek 7. Ocena poziomu wynagrodzenia}

Stać na zaspokojenie potrzeb i dodatkowo oszczędzanie

Stać na zaspokojenie potrzeb i przyjemności

Stać na zaspokojenie podstawowych potrzeb (tzn. opłaty, rachunki, żywienie)

Nie stać na zaspokojenie podstawowych potrzeb, musi korzystać z pomocy innych

$29 \%$

$33 \%$

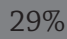

Źródło: opracowanie własne. 
Pozytywna ocena sprawiedliwości wynagradzania koreluje z poziomem satysfakcji z wykonywanej pracy. Satysfakcję odczuwa $73 \%$ ankietowanych pracowników, a jedynie 11\% jest przeciwnego zdania (rysunek 8). Współczynnik korelacji liniowej Pearsona między ogólną oceną sprawiedliwości wynagrodzenia a poziomem satysfakcji z pracy wynosi 0,310 . Wynik ten potwierdza przekonanie, że poczucie sprawiedliwości wynagrodzenia ma znaczenie dla satysfakcji z pracy. Badacze zauważają także wpływ oceny sprawiedliwości na poczucie własnej wartości, co ma istotne znaczenie dla gotowości do pracy i chęci współdziałania (Franken, 2006, s. 296).

Rysunek 8. Moja praca daje mi satysfakcję; jestem dumny/a z wykonywanej pracy; czuję się w pracy wykorzystywany/a

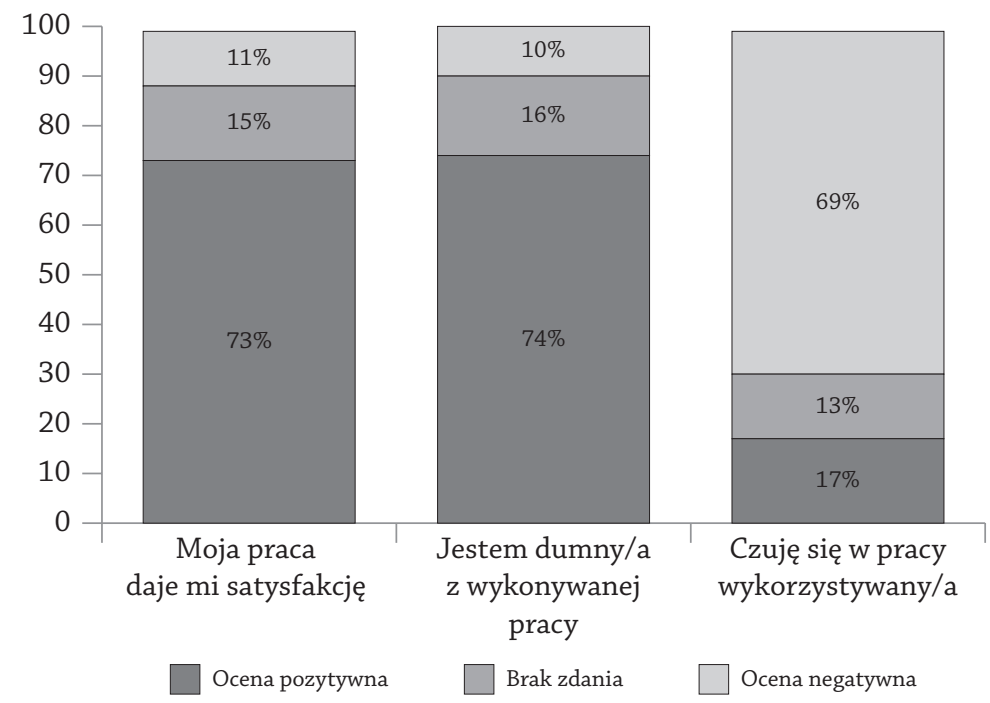

Źródło: opracowanie własne

Respondenci oceniają także pozytywnie inne aspekty pracy, które korelują z oceną sprawiedliwości wynagradzania (tabela 3). Dumę deklaruje $74 \%$ badanych, a 69\% zaprzecza, że jest wykorzystywany w miejscu pracy. Najwyższa korelacja oceny sprawiedliwości wynagradzania (na poziomie przeciętnym, bliskim -0,4) została uzyskana w przypadku wrażenia wykorzystywania w pracy. Nieco niższy współczynnik korelacji dotyczy dumy z wykonywanej pracy $(0,27)$.

Przedstawione wyniki dowodzą, że pozytywna ocena sprawiedliwości wynagrodzeń w Polsce kształtuje się także pod wpływem satysfakcji z wykonywanej pracy, determinowanej czynnikami związanymi z rodzajem pracy i sytuacją rynkową. 
Tabela 3. Korelacje między oceną sprawiedliwości wynagrodzenia a kluczowymi cechami wykonywanej pracy

\begin{tabular}{|l|l|c|}
\hline \multicolumn{1}{|c|}{ Pytanie } & \multicolumn{1}{c|}{ Miara } & Wynik \\
\hline Moja praca daje mi satysfakcję & współczynnik Pearsona & 0,310 \\
\hline Jestem dumny/a z wykonywanej pracy & współczynnik Pearsona & 0,270 \\
\hline Czuję się w pracy wykorzystywany/a & współczynnik Pearsona & $-0,389$ \\
\hline
\end{tabular}

Uwaga: $N=986$.

Źródło: opracowanie własne

Istotna wydaje się konstatacja, że ogólna satysfakcja z pracy jest wyższa (73\% odpowiedzi pozytywnych) niż satysfakcja z wynagrodzeń (49\% opinii pozytywnych). W tym kontekście można stwierdzić, że poziom wynagrodzeń wpływa pośrednio na ocenę sprawiedliwości, a bezpośrednio - na decyzje pracowników o wyborze pracodawcy oraz na współczynniki fluktuacji i retencji.

Kolejnym czynnikiem korzystnie wpływającym na odczucie sprawiedliwości wynagrodzeń jest dobra znajomość zasad wynagradzania. Stwierdza, że wie, jakie zasady decydują o ustaleniu wynagrodzenia, 69\% respondentów, $21 \%$ nie ma zdania na ten temat, a 18\% ich nie zna. Równocześnie jednak $28 \%$ ankietowanych uważa, że wynagrodzenia w ich firmach nie są jawne, a $11 \%$ nie ma na ten temat jednoznacznej opinii. Wydaje się, że sytuacja ta ogranicza transparentność kryteriów zróżnicowania wynagrodzeń, a tym samym utrudnia pracownikom zobiektywizowaną ocenę sprawiedliwości wynagradzania.

Pomimo ogólnie pozytywnej opinii pracowników na temat sprawiedliwości wynagrodzeń, wyniki wskazują na znaczne możliwości dalszej poprawy, gdyż $26 \%$ respondentów ocenia wynagrodzenia jako niesprawiedliwe, a $21 \%$ nie ma na ten temat jednoznacznej opinii (zob. rysunek 2). Rezerwy tkwią przede wszystkim w zróżnicowaniu wynagrodzeń, które 30\% respondentów ocenia negatywnie, a $22 \%$ nie ma zdania na ten temat (zob. rysunek 5). Poważny sygnał dla zarządzających powinna także stanowić skala braku satysfakcji z wynagrodzeń (zob. rysunek 6): $21 \%$ respondentów nie ma w tej sprawie zdania, a 30\% wynagrodzenie nie satysfakcjonuje.

\section{Podsumowanie}

Warunkiem wzrostu zaangażowania pracowników, w tym innowacyjności, skłonności do rozwoju i dzielenia się wiedzą, jest zapewnienie pracownikom poczucia sprawiedliwego wynagrodzenia. Złożoność istoty i zakresu tego zagadnienia 
wymaga analizy z trzech perspektyw: jakościowych cech wynagrodzenia za pracę, skuteczności systemu oraz percepcji pracowników.

Wyniki analizy teoretycznej oraz empirycznej pozytywnie weryfikują hipotezę badawczą, że głównym czynnikiem kształtującym poczucie sprawiedliwości wynagrodzeń są opinie pracowników na temat relacji wynagrodzeń. Korzystny wpływ wywiera także satysfakcja z wykonywanej pracy oraz znajomość zasad ustalania wynagrodzeń.

Warunkiem poczucia sprawiedliwości wynagrodzeń przez polskich pracowników jest zastąpienie tradycyjnego systemu wynagradzania w organizacji systemem proaktywnym, inspirującym, który zapewni zgodność między warunkami sprawiedliwości oraz efektywności. Zindywidualizowany charakter percepcji sprawiedliwości uzasadnia potrzebę monitorowania poczucia sprawiedliwości systemu wynagrodzeń (Warwas, Rogozińska-Pawełczyk, 2016, s. 41).

Badania dowodzą, że mimo ogólnie pozytywnej opinii polskich pracowników na temat sprawiedliwości wynagrodzeń, celowe jest podjęcie działań w zakresie kryteriów i mechanizmów różnicowania oraz transparentności wynagradzania. Istotny problem zarządczy stanowi niezadowalający poziom satysfakcji pracowników z wynagrodzeń.

\section{Bibliografia}

Adams, J.S. (1963). Towards an Understanding of Inequity. Journal of Abnormal and Social Psychology, 67(5), 422-436.

Borkowska, S. (2012). Skuteczne strategie wynagrodzeń - tworzenie i zastosowanie. Warszawa: Oficyna Wolters Kluwer business.

Borkowska, S. (1999). Sprawiedliwość i płaca sprawiedliwa. W: S. Borkowska (red.), Wynagrodzenie godziwe. Koncepcja i pomiar. Warszawa: IPiSS, 19-29.

Boston Consulting Group, Inc. and World Federation of Personnel Management (2008). Associations Creating People Advantage. How to Address HR Challenges Worldwide Through 2015. http://www.aidp.it/aidp/ALLEGATI/FILES/3404.pdf (8.08.2018).

Card, D., Mas, A., Moretti, E., Saez, E. (2012). Inequality at work: The effect of peer salaries on job satisfaction. American Economic Review, 102(6), 2981-3003.

Carr, S.C., Parker, J., Arrowsmith, J., Watters, P.A. (2016). The living wage: Theoretical integration and an applied research agenda. International Labour Review, 155(1), $1-24$.

Deloitte University Press (2015). Global Human Capital Trends 2015: Leading in the new world of work. https://www2.deloitte.com/content/dam/Deloitte/be/Documents/ 
human-capital/2015_HC_brochure_2015_Trends_Belgian_report-web.pdf (8.08.2018).

Europejska Karta Społeczna sporządzona w Turynie dnia 18 października 1961 r. Dz.U. z 1999 r. Nr 8, poz. 67. https://www.mpips.gov.pl (23.04.2018).

Franken, R.E. (2006). Psychologia motywacji. Gdańsk: Gdańskie Wydawnictwo Psychologiczne.

Juchnowicz, M. (2014). Charakterystyka zarządzania kapitałem ludzkim na tle koncepcji zasobowej. W: M. Juchnowicz (red.), Zarzadzanie kapitałem ludzkim. Procesy - narzędzia - aplikacje. Warszawa: PWE, 132-136.

Koźmiński, A.K. (2017). Wyobraźnia ekonomiczna i ekonomia społecznych emocji. Biuletyn PTE, 4(79), 19-22.

Kulikowski, K. (2017). Jak wysokość wynagrodzenia wiąże się z oceną sprawiedliwości wynagrodzenia i zadowoleniem z pracy? Analiza na podstawie Ogólnopolskiego Badania Wynagrodzeń 2015. Zeszyty Naukowe Politechniki Śląskiej, 105, 227-240.

Rasch, R., Szypko, M. (2013). Perception is Reality: The Imortance of Pay Fairness to Employees and Organizations. WorldatWork Journal, Third Quarter, 65-74.

Sekuła, Z. (2013). Struktury wynagradzania pracowników. Warszawa: Oficyna Wolters Kluwer.

Ustawa z dnia 26 czerwca 1974 r. - Kodeks pracy. Dz.U. Nr 24, poz. 141. http://prawo. sejm.gov.pl (23.04.2018).

Vaughan-Whitehead, D. (2011). How fair are wage practices along the supply chain? Global assessment in 2010-2011. Paper prepared for the Better Work Conference, 26-28 October 2011, Washington, DC.

Vielmetter, G., Sell, Y. (2014). Leadership 2030: The Six Megatrends You Need to Understand to Lead Your Company into the Future. New York: AMACOM.

Warwas, I., Rogozińska-Pawełczyk, A. (2016). Zarzqdzanie zasobami ludzkimi w nowoczesnej organizacji. Łódź: Wydawnictwo Uniwersytetu Łódzkiego.

\section{Summary}

\section{Essence of Fair Remuneration in Management Theoretical and Practical Aspects}

The importance of human capital as well as a shift in the employee value systems, reflected in growth of sensitivity to social injustice, substantiate the increased interest in the analysis of fair remuneration as a category that causes diverse consequences at a microeconomic level of management, therefore from the individual and organizational perspectives. The aim of this paper is a theoretical and empirical exploration of the essence of fair remuneration. The 
complexity of this category requires analysis from several perspectives: qualitative characteristics of salaries, efficiency of the organizational remuneration scheme and the individual employee attitude. The paper also contains the analysis of various dimensions of fair remuneration based on the opinions of individuals employed on the Polish labor market. On this basis the impact of fair remuneration management is formulated at an organizational level.

Keywords: wage, fair remuneration, decent pay, remuneration scheme

\section{Prof. dr hab. Marta Juchnowicz}

Dyrektor Instytutu Kapitału Ludzkiego Szkoły Głównej Handlowej w Warszawie, Redaktor Naczelna czasopisma Edukacja Ekonomistów i Menedżerów, członek prezydium KNoPiPS PAN. 